\title{
Characterization of the bacterially-active particle fraction in the Columbia River estuary
}

\author{
Byron C. Crump*, John A. Baross \\ School of Oceanography, University of Washington, Seattle, Washington 98195, USA
}

\begin{abstract}
The Columbia River estuary is dominated by a detrital food web that feeds primarily on river-borne particulate organic material in the estuarine turbidity maxima (ETM). Approximately $90 \%$ of the bacterial activity and most of the extracellular enzyme activity in the water column of the estuary were associated with particles captured by a $3 \mu \mathrm{m}$ filter. Earlier studies determined that the relationship between particle-attached bacterial activity and suspended particulate mass (SPM) was variable, suggesting that some particles supported a larger fraction of bacterial activity. In order to characterize these bacterially-active particles, suspended particulate material from the estuary was fractionated by size and in situ settling velocity, and analyzed for ${ }^{3} \mathrm{H}$-thymidine incorporation rate, total particle mass and particulate organic carbon (POC) concentration. The location and movement of bacterially-active particles in the estuary was traced by measuring ${ }^{3} \mathrm{H}$-thymidine incorporation rate and SPM in nearbottom depth profiles collected at 4 or 5 time points during ETM resuspension events. The smallest particle size fraction (3 to $10 \mu \mathrm{m}$ ) supported $87 \%$ ( $\mathrm{SE}=13$ ) of bacterial activity, but contained only $38 \%$ $(\mathrm{SE}=5)$ of total POC and $38 \%(\mathrm{SE}=6)$ of total particle mass. However, when particles were separated by in situ settling velocity using a method that preserved the integrity of aggregated particles, the settling velocity of the majority of bacterially-active particles varied from $<0.07 \mathrm{~mm} \mathrm{~s}^{-1}$ in some samples to $>0.75 \mathrm{~mm} \mathrm{~s}^{-1}$. Microscopic analysis of bacterially-active particles revealed that they were aggregates of smaller $(<10 \mu \mathrm{m})$ particles held together by a transparent matrix. This study shows that small, slowsettling particles host most of the bacterial activity in the Columbia River estuary, and suggests that they contain the most rapidly consumed pool of organic matter in the system. Furthermore, it demonstrates that the configuration of these particles may be highly dynamic as they are regularly aggregated and disaggregated in ETM. In the estuary, these particles often appeared in the water column early during developing flood tides prior to the appearance of the most turbid part of ETM, and sometimes remained in the water column after most ETM particles had settled back to the bed. This cycle places bacterially-active particles in the water column longer than most ETM particles, making them more likely to be washed out of the estuary, but also making them more available to suspension-feeding detritivores. Formation of large, fast-settling macroaggregates during the late stages of flood and ebb tides and during slack tides is probably the mechanism by which bacterially-active particles are trapped in the ETM, and may be essential to maintaining the estuarine community of particle-attached bacteria.
\end{abstract}

KEY WORDS: Estuary $\cdot$ Aggregates $\cdot$ Bacteria $\cdot$ Columbia River

Resale or republication not permitted without written consent of the publisher

\section{INTRODUCTION}

Particle formation in estuaries and particle cycling in estuarine turbidity maxima (ETM) have been extensively studied (Schubel 1971, Kranck 1981, Gibbs et al. 1989, Eisma \& Li 1993, Li et al. 1993, Chen et al. 1994), but relatively little has been presented on the connection between these processes and the estuarine food

*E-mail: bcrump@mbl.edu web. A principle complicating issue in studying the ecology of ETM is that they are not homogeneous, well-mixed masses of particles. Particles composed of labile organic material that host actively growing bacteria coexist with mineral grains, refractory organic material and other less active particles. Fluxes of particles into and out of ETM vary on many time scales, and the composition of the suspended particle field varies in space and time during individual ETM events (Li et al. 1993). Physical and chemical measurements of par- 
ticles in estuaries, most often conducted on bulk particles, are likely to be misleading when trying to interpret biological data. For example, the presence of large amounts of refractory organic matter could mask the composition and rate of consumption of relatively labile organic matter.

Past work on the Columbia River estuary indicated that the estuarine food web is dependent on the physical and geochemical environment of ETM (Simenstad et al. 1994b, Morgan et al. 1997, Crump et al. 1998). The hydrodynamics that trap and concentrate particles in the ETM also trap and concentrate particle-attached bacteria, copepods, and other members of the food web. In this system, particle-attached bacteria dominate bacterial activity (Crump \& Baross 1996, Crump et al. 1998), and detritivorous copepods are the most important metazoan grazers (Simenstad et al. 1994b). These bacteria and copepods feed primarily on detrital organic material concentrated in the ETM (Simenstad et al. 1994b, Crump \& Baross 1996, Crump et al. 1998). The ETM environment is the center of the planktonic food web in the Columbia River estuary and is probably important in other river-dominated estuaries.

The relationship between bacterial activity and suspended particle mass (SPM) in the Columbia River estuary was highly variable even within a single ETM. High rates of bacterial production, measured as ${ }^{3} \mathrm{H}$-thymidine incorporation rate, were often found in samples collected just prior to peak water column turbidity (Crump et al. 1998). Moreover, in depth profiles of bacterial activity through an ETM, the highest bacterial activity was often found in relatively less turbid water above the main ETM (Crump \& Baross 1996). We hypothesize that a fraction of the particles in the ETM hosts the majority of the bacterial activity, and that these particles are cycled within ETM in a different manner than the majority of ETM particles. In this study, particles were fractionated by size and in situ settling velocity in order to characterize the most bacterially active particles. Also, ETM events were intensely sampled for bacterial activity, SPM and particulate organic carbon (POC) in order to track the cycling of bacterially active particles. A model of bacterially active particle cycling in the ETM is proposed.

\section{MATERIALS AND METHODS}

Sample collection. Size fractionation experiments: Water samples for particle size fraction analyses were collected from ETM in July 1996 with a high-volume, low-pressure pump coupled to a conductivity-temperature-depth (CTD) meter and an optical backscatter sensor (OBS) for measuring turbidity in relative OBS units
(Simenstad et al. 1994a). These samples were poured through a series of Nytex screens $(63,20$ and $10 \mu \mathrm{m})$ and were subsampled after each screen. Some of the filtrate was then filtered through a $3 \mu \mathrm{m}$ polycarbonate filter as previously described (Crump et al. 1998). The rate of ${ }^{3} \mathrm{H}$-thymidine incorporation, suspended particulate mass (SPM), and particulate organic carbon concentration (POC) were measured in untreated water and in each filtrate.

Particles collected from each Nytex screen and $<10 \mu \mathrm{m}$ subsamples were fixed in formaldehyde $(2 \%)$, collected onto $0.2 \mu \mathrm{m}$ polycarbonate filters (Poretics), and viewed with an environmental scanning electron microscope (FIE Company).

In situ settling velocity fractionation: In situ settling velocity spectra of ${ }^{3} \mathrm{H}$-thymidine incorporation rate, SPM and POC was determined with a 'Quad Owen tube' consisting of 4 individual Braystoke Sk 110 settling columns (Owen 1976, Pejrup 1988) attached sideto-side. Each clear plastic tube was $1 \mathrm{~m}$ in length with a $5.1 \mathrm{~cm}$ internal diameter. For each sample, the set of tubes was lowered over the side of the ship. Stabilizing fins aligned the tubes to the flow of water in a horizontal position, allowing water and particles at a discrete depth to pass through all 4 tubes. The ends of the tubes were simultaneously closed with a messenger, brought on deck, and set in a special rack that held them in a vertical position. Sample fractions were drawn from the bottom of the tube at fixed time intervals (Table 1). The Quad Owen tube was used in order to have enough material for multiple analyses. Generally, 1 tube was used for SPM, a second tube was used for ${ }^{3} \mathrm{H}$-thymidine incorporation rates, and a third tube was used for POC. ${ }^{3} \mathrm{H}$-thymidine incorporation rate and SPM were measured in Owen tube samples collected in May 1995 and October 1997. POC was measured in Owen tube samples from 1997.

Settling velocity spectra were calculated using a mathematical version of Owen's (1976) original graphical method (Larry Sanford pers. comm.).

Table 1. Time elapsed in minutes (min) and seconds (s) before each fraction was collected from Owen tubes

\begin{tabular}{|ccc|}
\hline $\begin{array}{c}\text { Owen tube } \\
\text { fraction \# }\end{array}$ & 1995 & $1997-1998$ \\
\hline 1 & 1 min $14 \mathrm{~s}$ & 1 min $2 \mathrm{~s}$ \\
2 & $12 \min 1 \mathrm{~s}$ & $5 \min 45 \mathrm{~s}$ \\
3 & $28 \min 29 \mathrm{~s}$ & $12 \min 3 \mathrm{~s}$ \\
4 & Final & $19 \min 18 \mathrm{~s}$ \\
5 & & $27 \min 48 \mathrm{~s}$ \\
6 & & $40 \min 36 \mathrm{~s}$ \\
7 & & $41 \min 48 \mathrm{~s}$ \\
8 & & Final \\
\hline
\end{tabular}




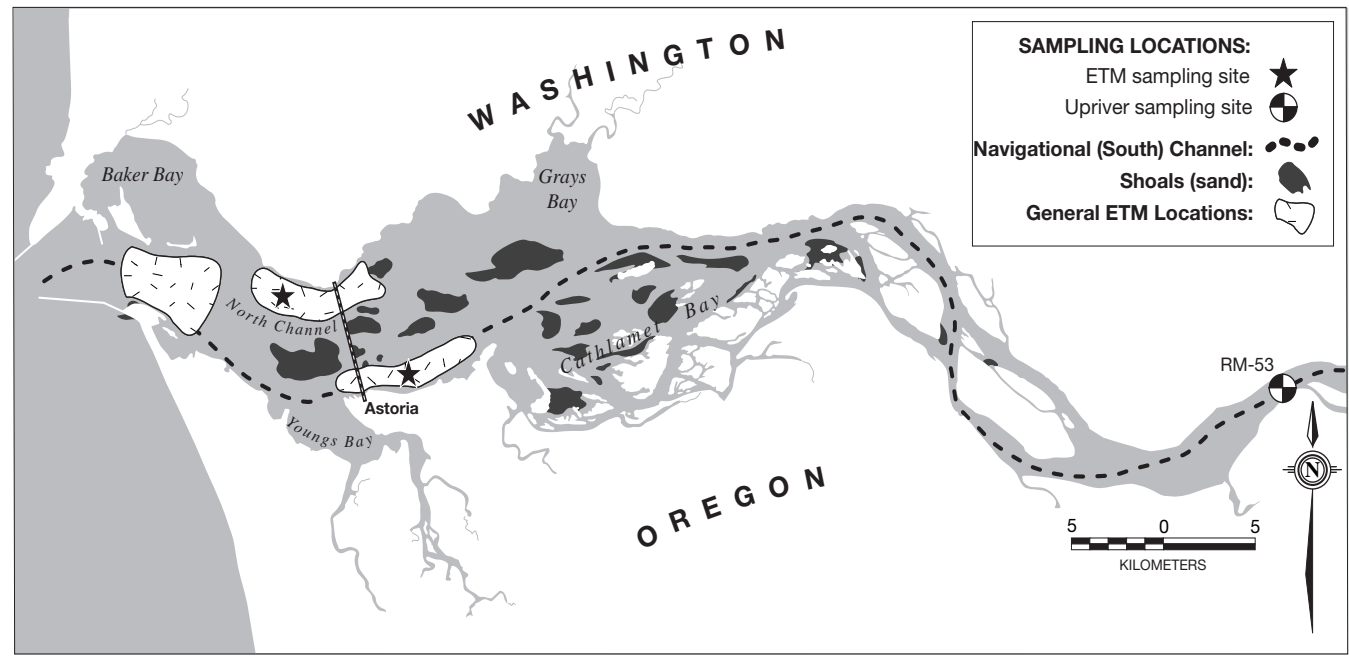

Fig. 1. Columbia River estuary. Sampling sites in the North and South Channels of the estuary and upriver are indicated

High-resolution ETM sampling: ETM resuspension events were intensely sampled during flood and ebb tides in May, July and October 1997 and February 1998. Water samples were collected with the pump system described above from $0.5,1,1.5,2$, and $2.5 \mathrm{~m}$ above the bed of the estuary in the North Channel (Fig. 1). Sampling times were selected to bracket ETM events by sampling before, during and after peak water column turbidity, and were therefore not always at fixed intervals. The rate of ${ }^{3} \mathrm{H}$-thymidine incorporation, SPM and POC were measured in each water sample.

Measurements. Thymidine incorporation rates were determined by measuring the incorporation of methyltritiated thymidine (TdR., Fuhrman \& Azam 1982) (20 nM final conc. at $64 \mathrm{Ci} \mathrm{mmol}^{-1}$ ) into the cold trichloroacetic acid (TCA) insoluble fraction of macromolecules in four $10 \mathrm{ml}$ (1995) or six $5 \mathrm{ml}$ (1997-98) subsamples incubated with constant agitation at in situ temperature. Duplicate (or triplicate) incubations were terminated at 0 and 60 min with $0.25 \mathrm{M} \mathrm{NaOH}$ (final conc., Zweifel et al. 1995). TCA precipitated macromolecules were washed twice with ice cold $5 \%$ TCA and twice with ice cold $80 \%$ ethanol (Crump \& Baross 1996, Crump et al. 1998).

SPM in size fraction experiments was determined by filtering the material in a known volume of sample onto pre-weighed $0.45 \mu \mathrm{m}, 47 \mathrm{~mm}$ diameter polycarbonate filters. SPM in Owen tube experiments was determined by filtering each fraction onto preweighed $0.45 \mu \mathrm{m}, 47 \mathrm{~mm}$ diameter cellulose acetate filters. Filters were washed with fresh water, dried and weighed (Reed \& Donovan 1994).

POC and PON were determined on samples filtered through precombusted GF/F filters, dried, and processed with a Leeman Labs CE440 CHN analyzer calibrated with an acetanilide standard.
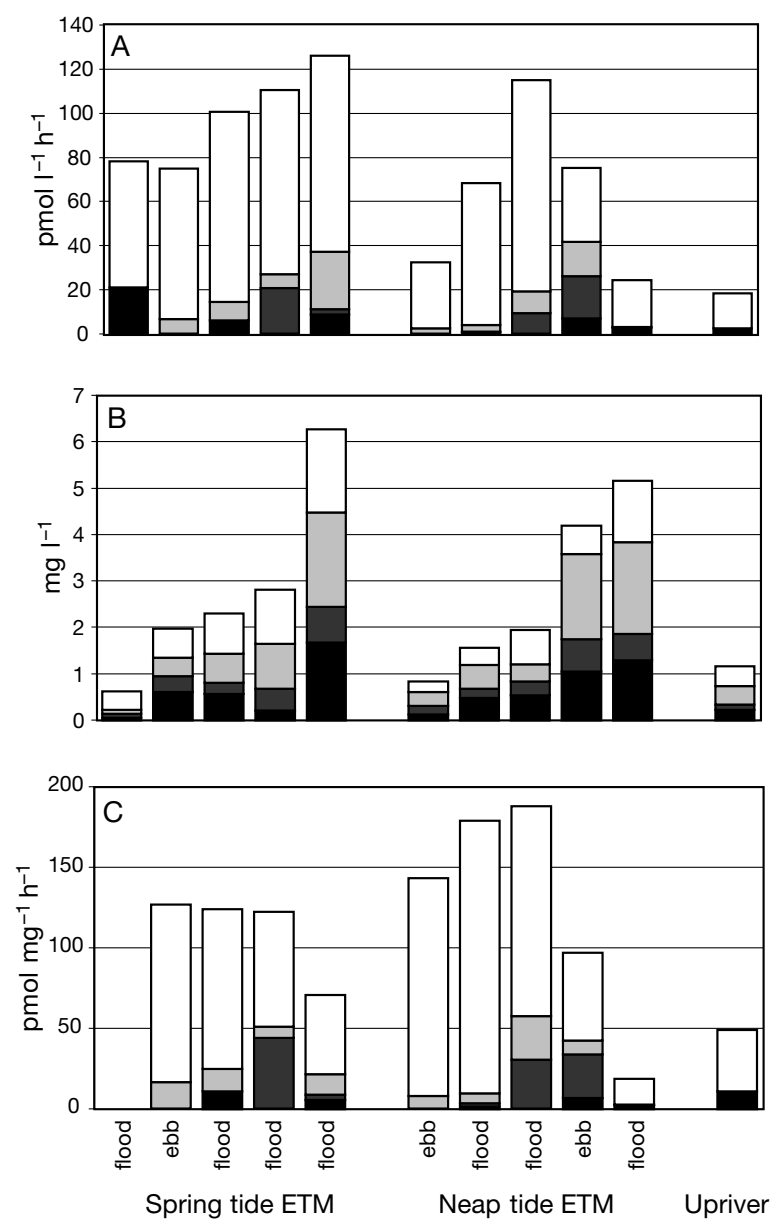

Fig. 2. Thymidine incorporation rate $\mathrm{l}^{-1}(\mathrm{~A}), \mathrm{POC}$ concentration (B) and thymidine incorporation rate $\mathrm{mg}^{-1} \mathrm{POC}$ (C) for 4 size fractions (lightest to darkest shading: $3-10,10-20,20-63$, and $>63 \mu \mathrm{m}$ ) in 5 spring tide flood and ebb ETM samples collected 9-10 July 1996, in 5 neap tide flood and ebb ETM samples collected 19-20 July 1996, and in 1 upriver sample collected 18 July 1996. Flood and ebb tide ETM samples are indicated 
Table 2. Organic carbon content and carbon-to-nitrogen ratios of particle size fractions with standard deviations (SD)

\begin{tabular}{|ccccc|}
\hline $\begin{array}{l}\text { Size fractions } \\
(\mu \mathrm{m})\end{array}$ & $\begin{array}{c}\text { \% organic } \\
\text { carbon }\end{array}$ & $\begin{array}{c}\mathrm{SD} \\
\%\end{array}$ & $\begin{array}{c}\mathrm{C} / \mathrm{N} \\
\text { ratio }\end{array}$ & $\mathrm{SD}$ \\
\hline$>63$ & 9.6 & 6.5 & 6.5 & 2.4 \\
$20-63$ & 5.2 & 2.7 & 9.5 & 3.9 \\
$10-20$ & 3.5 & 2.5 & 7.6 & 0.9 \\
$3-10$ & 3.7 & 0.5 & 7.6 & 1.4 \\
\hline
\end{tabular}

\section{RESULTS}

Bacteria associated with particles between 3 and $10 \mu \mathrm{m}$ were responsible for the majority of bacterial thymidine incorporation in all samples; however, only a fraction (38\% on average) of total POC was associated with these particles (Fig. 2). Bacterial activity $\mathrm{mg}^{-1}$ POC was highest in the smallest particle size fraction. The smallest size fraction averaged $3.7 \%$ organic carbon by weight and had an average carbon to nitrogen ratio $(\mathrm{C} / \mathrm{N})$ of 7.6 (Table 2). The larger size fractions were more variable in percent organic carbon and $\mathrm{C} / \mathrm{N}$, and tended to be higher in percent organic carbon.
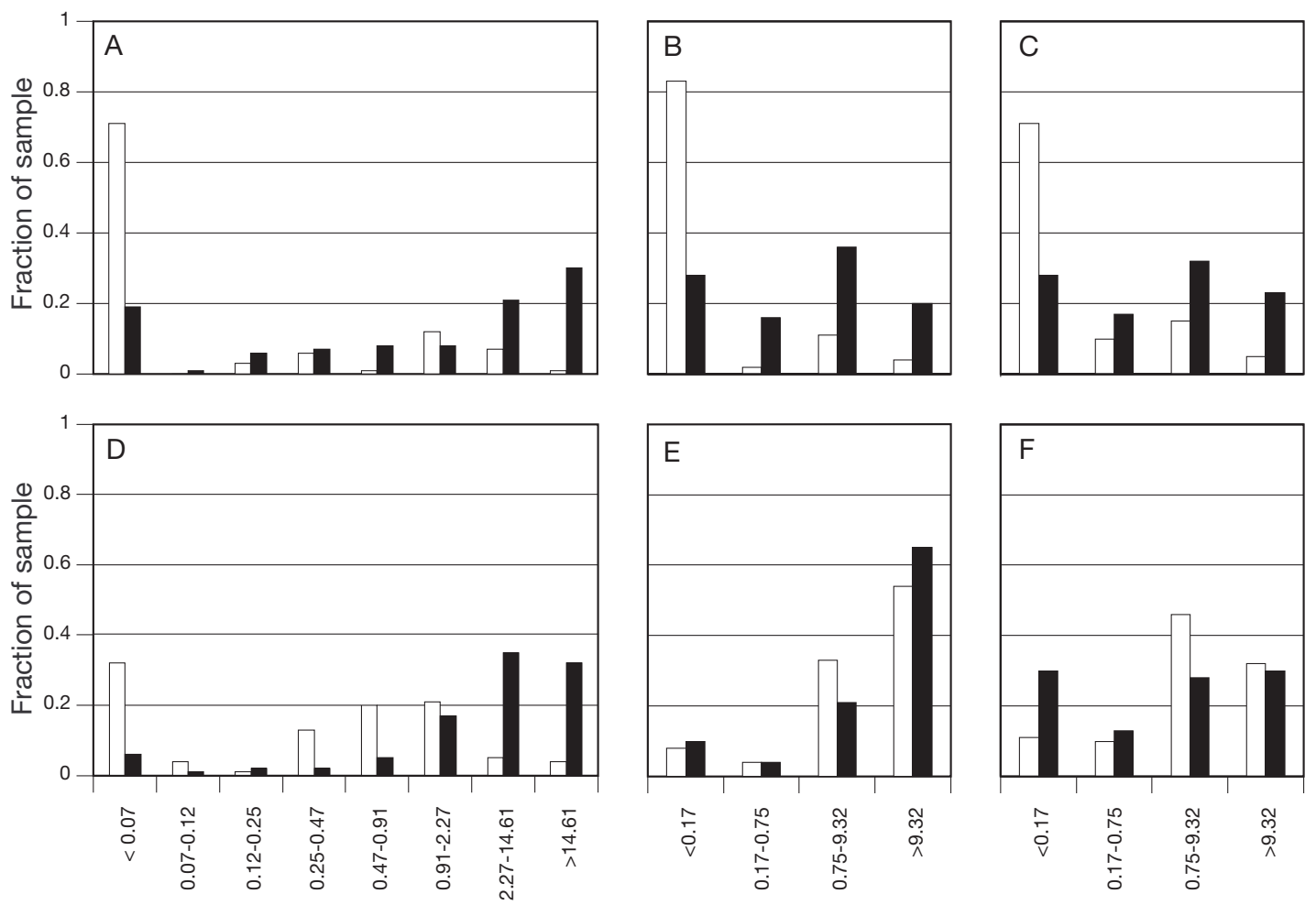

Settling velocity fractions $\left(\mathrm{mm} \mathrm{s}^{-1}\right)$

Fig. 3. Fraction of thymidine incorporation rate (white columns) and suspended particulate mass (dark columns) associated with settling velocity fractions in flood tide ETM samples collected in 1997-1998 (samples A and D), and in 1995 (samples B, C, E, and F) 
Fig. 4. Near-bottom depth profiles of thymidine incorporation rates (pmol $\mathrm{l}^{-1} \mathrm{~h}^{-1}$, dots connected by lines) and suspended particulate mass ( $\mathrm{mg} \mathrm{l}^{-1}$, connected by line and shaded for clarity) during 4 flood tide ETM resuspension events sampled in spring, summer and fall 1997, and in winter 1998. The time on each panel indicates the time the deepest sample was collected. Shallower samples were collected in sequence after collecting the deepest sample. Note that the units of thymidine incorporation rates and suspended particulate mass are consistent within each high resolution sampling series, but may differ between seasons ples, bacterial activity was concentrated on particles with settling velocities greater than $0.75 \mathrm{~mm} \mathrm{~s}^{-1}$ (Fig. 3E,F). Organic carbon content was higher for particles with slower settling velocities (Table 3).

High resolution sampling of ETM showed the highest measurements of water column bacterial activity occurred during ETM events, but were not always associated with peaks in turbidity. During a flood tide ETM event sampled in the Spring (Fig. 4A), maximum bacterial activity was measured in the last sample (panel 4) approximately 30 min after peak turbidity (panel 2). During a summer flood tide, bacterial activity was highest in relatively low turbidity water $45 \mathrm{~min}$ prior to peak turbidity (Fig. 4B, panel 2). Moreover, when turbidity was at its maximum near the bed, bacterial activity was greatest in less turbid water higher in the water column (Fig. 4B, panel 3). Also, 30 min after peak turbidity, bacterial activity remained relatively high (Fig. 4B, panel 4).
A. Spring. May 6,1997
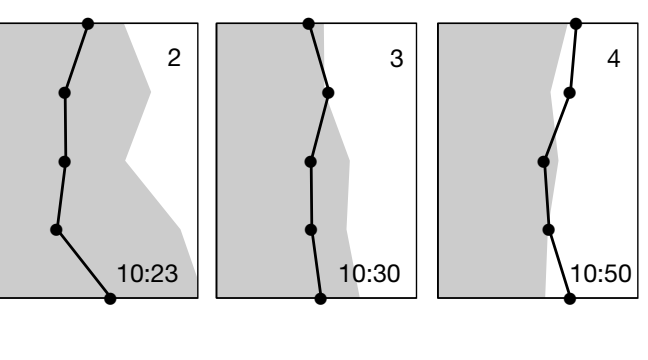

B. Summer. July 16,1997
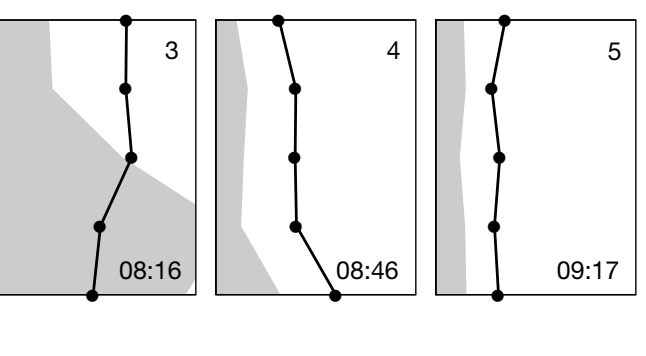

C. Fall. Oct. 14, 1997
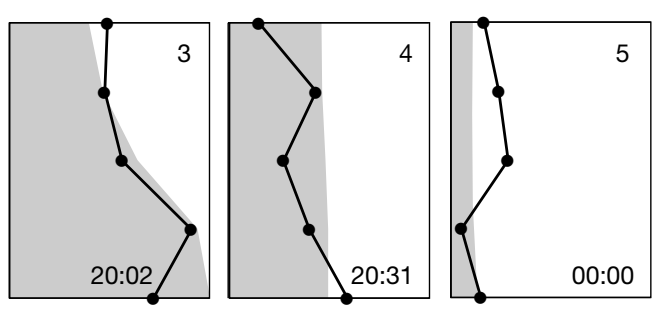

D. Winter. Feb. 23, 1998
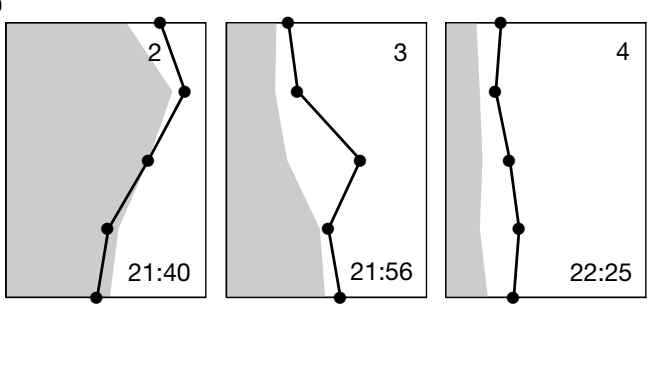

During flood tide ETM sampled in the fall and winter (Fig. 4C,D), bacterial activity appeared to follow turbidity, although there was a pulse of relatively high bacterial activity near the bed 15 min prior to the onset of the ETM in the fall series (Fig. 4C, panel 1). During a spring ebb tide, bacterial activity was highest early in the ETM event and dropped off later when turbidity was slightly higher (Fig. 5A). During a fall ebb tide, bacterial activity became very high $30 \mathrm{~min}$ prior to peak turbidity (Fig. 5B, panel 2), and remained high as turbidity began to drop off (panel 4). The winter ebb 

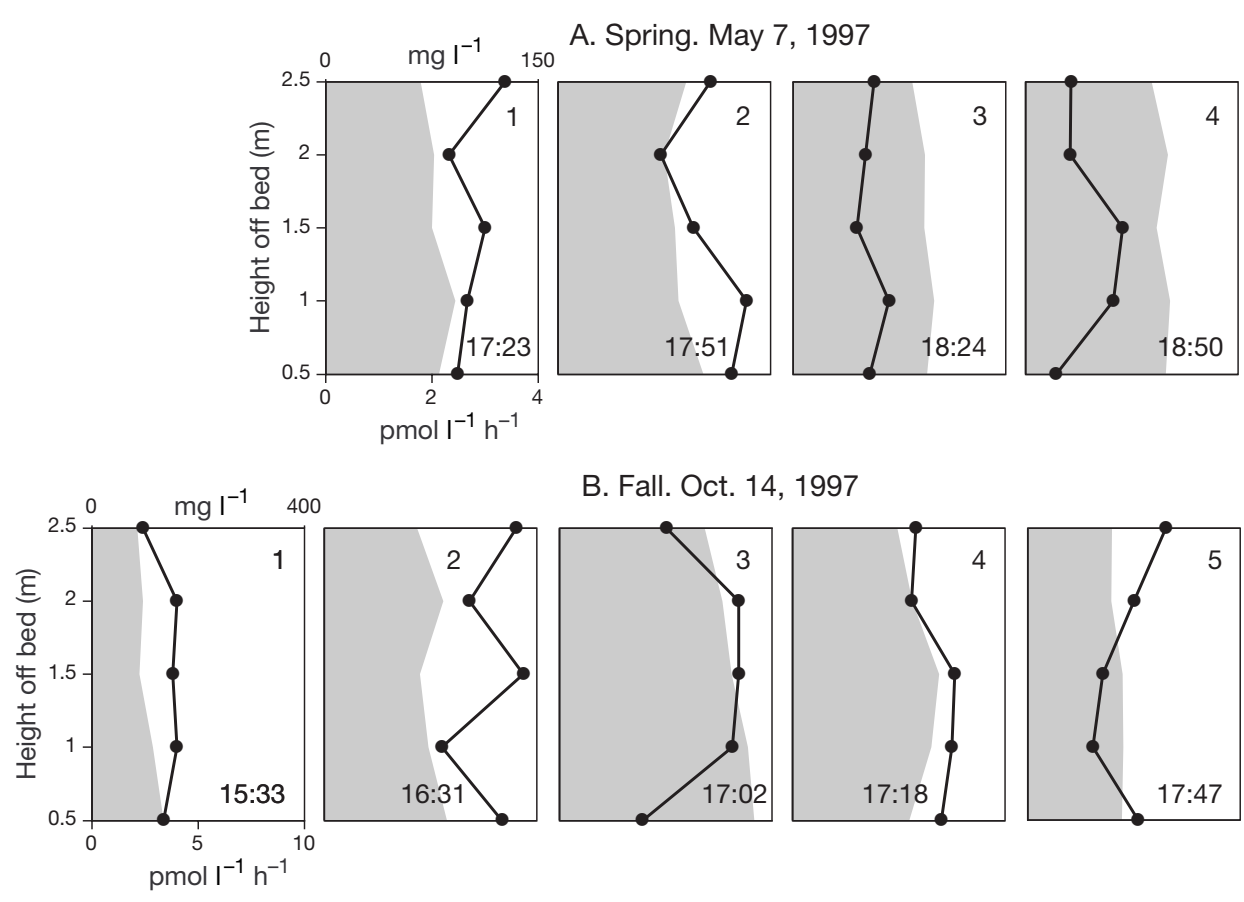

B. Fall. Oct. 14, 1997

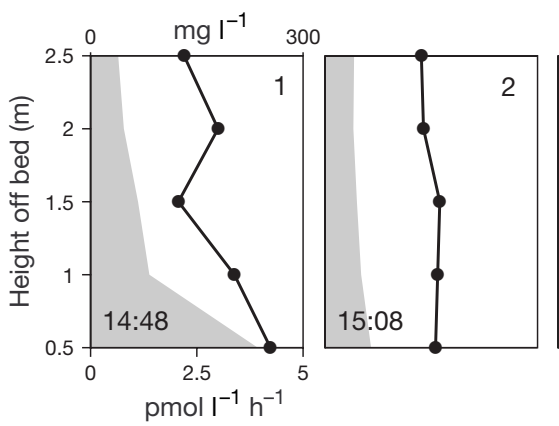

C. Winter. Feb. 23, 1998

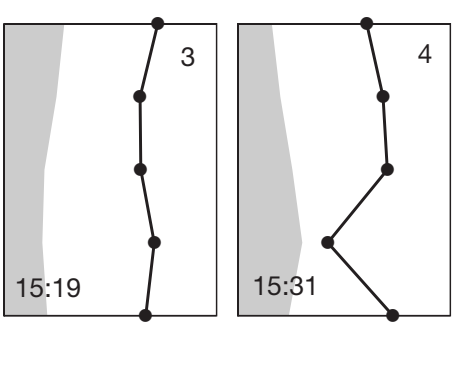

Fig. 5. Near-bottom depth profiles of thymidine incorporation rates (dots connected by lines) and suspended particulate mass (connected by line and shaded for clarity) during ebb tide ETM events. Note that the units of thymidine incorporation rates and suspended particulate mass are consistent within each high resolution sampling series, but may differ between seasons

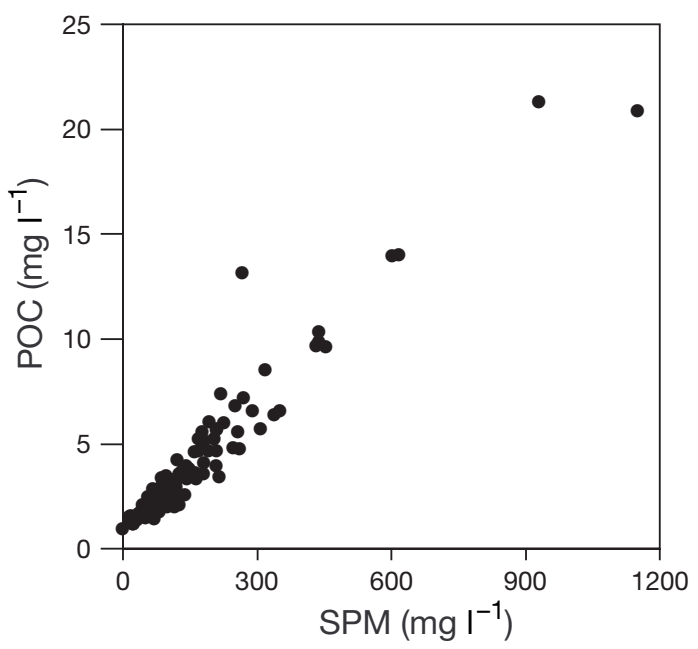

Fig. 6. Suspended particulate mass vs particulate organic carbon concentration for samples displayed in Figs. 4 \& 5

tide ETM was not very strong, and bacterial activity in the water column was somewhat constant (Fig. 5C).

Salinity near the bed of the estuary at the North Channel sampling site (Fig. 1) can vary from 0 to nearly that of coastal seawater, and ETM generally appear in the water column at some intermediate salinity during the progression of flood and ebb tide. During flood tide, high resolution sampling series in the spring, summer and winter (Fig. 4A,B,D), peak bacterial activity and peak water column turbidity appeared when salinity was between 10 and $15 \mathrm{psu}$. These series began at 5 to $10 \mathrm{psu}$, and ended at 21 to $22 \mathrm{psu}$. In the fall series (Fig. 4C) salinity increased from 2 to 7 psu with peak turbidity appearing at 7 psu. Ebb tide ETM (Fig. 5) appeared at lower salinities between 1 and 5 psu, probably because near bed water velocity is not very strong until later during an ebb tide. The spring and fall series (Fig. 5A,B) began at 8 to $10 \mathrm{psu}$ and ended at $1 \mathrm{psu}$. The winter series (Fig. 5C) began at 2 psu and ended at 1 psu. 
There was a strong correlation between SPM and POC in all high resolution samples from all 4 seasons (Fig. 6).

\section{DISCUSSION}

It is clear that all particles in the Columbia River estuary do not equally support bacterial activity. Small particles $(<10 \mu \mathrm{m})$ supported 45 to $100 \%$ of bacterial activity despite carrying only 14 to $65 \%$ of POC. These particles support 5 to 50 times more bacterial activity $\mathrm{mg}^{-1}$ POC than other particles, are probably composed of the most rapidly consumed fraction of organic matter in the estuary, and may be the most important food source to the detrital food web.

Observations using fluorescence microscopy and environmental scanning electron microscopy showed that most of the material in the $<10 \mu \mathrm{m}$ size fraction was small mineral grains and broken diatom frustules bound together by what appeared to be an organic matrix (Fig. 7). The 10-20 $\mu \mathrm{m}, 20-63 \mu \mathrm{m}$, and >63 $\mu \mathrm{m}$ size fractions contained some large aggregated particles, but were dominated by intact diatoms, individual mineral grains and large pieces of metazoans, which may explain why they tended to have a larger organic carbon content. The process of passing particles through Nytex screens was probably destructive to larger aggregated particles, breaking them up into individual mineral grains and cohesive micro-aggregates that could pass through the $10 \mu \mathrm{m}$ screen. Previous work on the Columbia River estuary showed that these types of particles can be heavily colonized with bacteria (Crump \& Baross 1996). It is likely that bacterially-active particles in the estuary are composed of this aggregated material.

Aggregated particles are amongst the most abundant types of particles in ETM. The composition of estuarine aggregates has been extensively studied in laboratory experiments (Sakamoto 1972, Kranck 1973, Milligan 1995) and in the field (Eisma 1986, Gibbs et al. 1989, Li et al. 1993). Loosely-bound macroaggregates, as large as several $\mathrm{mm}$ in diameter, are composed of smaller, more tightly-bound microaggregates $(<100 \mu \mathrm{m})$ and larger mineral grains. These microaggregates are composed primarily of small mineral grains with organic coatings bound to phytodetritus, flocculated DOC, and small bits of riverborne detritus. Marine and lake 'snow' particles differ from estuarine aggregates in that they are primarily composed of organic matter to which inorganic material subsequently attaches (Eisma 1986).

Bacteria are thought to play a key role in the formation of aggregates in estuaries. Particles encounter one another through Brownian motion, differential settling and the turbulent motion of water, but particle adhe- sion is facilitated in part by biologically produced polymeric material (Eisma 1986). In laboratory incubations of DOC, granite-derived till and powdered Spartina material it was found that larger aggregates formed after 24 to $48 \mathrm{~h}$ coincidentally with the development of a microbial community, suggesting the importance of bacterially-produced exudates in 'gluing' larger particles together (Muschenheim et al. 1989). Bacterial production of exopolysaccharide probably helps bind together aggregates in the Columbia River ETM, especially while particles are concentrated on or near the bed during slack tide.

Besides their role in the formation and structural integrity of estuarine aggregates, bacteria on particles also contribute to the estuarine food web. Particleattached bacteria increase the food value of particles to metazoan consumers as part of the detrital food web (Heinle et al. 1977). Flocculant particles in the Ems and the Elbe estuaries (Germany) were shown to be colonized by bacteria and protozoa and in the Elbe estuary to be colonized by rotifers (Muschenheim et al. 1989, Zimmerman \& Kausch 1996). In the Columbia River estuary copepods directly consume particles and particle-attached bacteria (Simenstad et al. 1994b). Bacterially-active particles probably contain some of the most labile organic matter in the estuary and therefore may be the best food source for metazoan detritovores.

\section{Settling velocity spectra}

The majority of bacterially-active particles in 3 ETM Owen tube samples had relatively slow-settling velocities of less than $0.007 \mathrm{~cm}$ (or $24.6 \mathrm{~cm} \mathrm{~h}^{-1}$ ). Early work in the Tamar estuary (England) also found 'non-sinking' particles to be much more bacterially active than particles that sank (Goulder 1977). This seems to be in conflict with the idea that, in order for particles to become trapped and concentrated in ETM and avoid being washed out of the estuary, they must be able to sink into deeper water and settle to the bed (Reed \& Donovan 1994). The most probable mechanism for concentrating slow and non-settling particles in ETM is aggregation with other particles to form rapidly settling macroaggregates. Cycles of aggregation and disaggregation occur with every tide in the ETM of the Columbia River estuary (Reed \& Donovan 1994), and have been described for other systems. Research on the ETM of the Elbe estuary found that floc size changed with the tidal cycle such that larger flocs resuspended from the bed were disaggegated by shear flow during periods of peak flow, only to reform during slack tides and settle to the bed (Chen et al. 1994). In the Dollard estuary (The Netherlands), aggregation is thought to occur throughout the tidal cycle, and disag- 

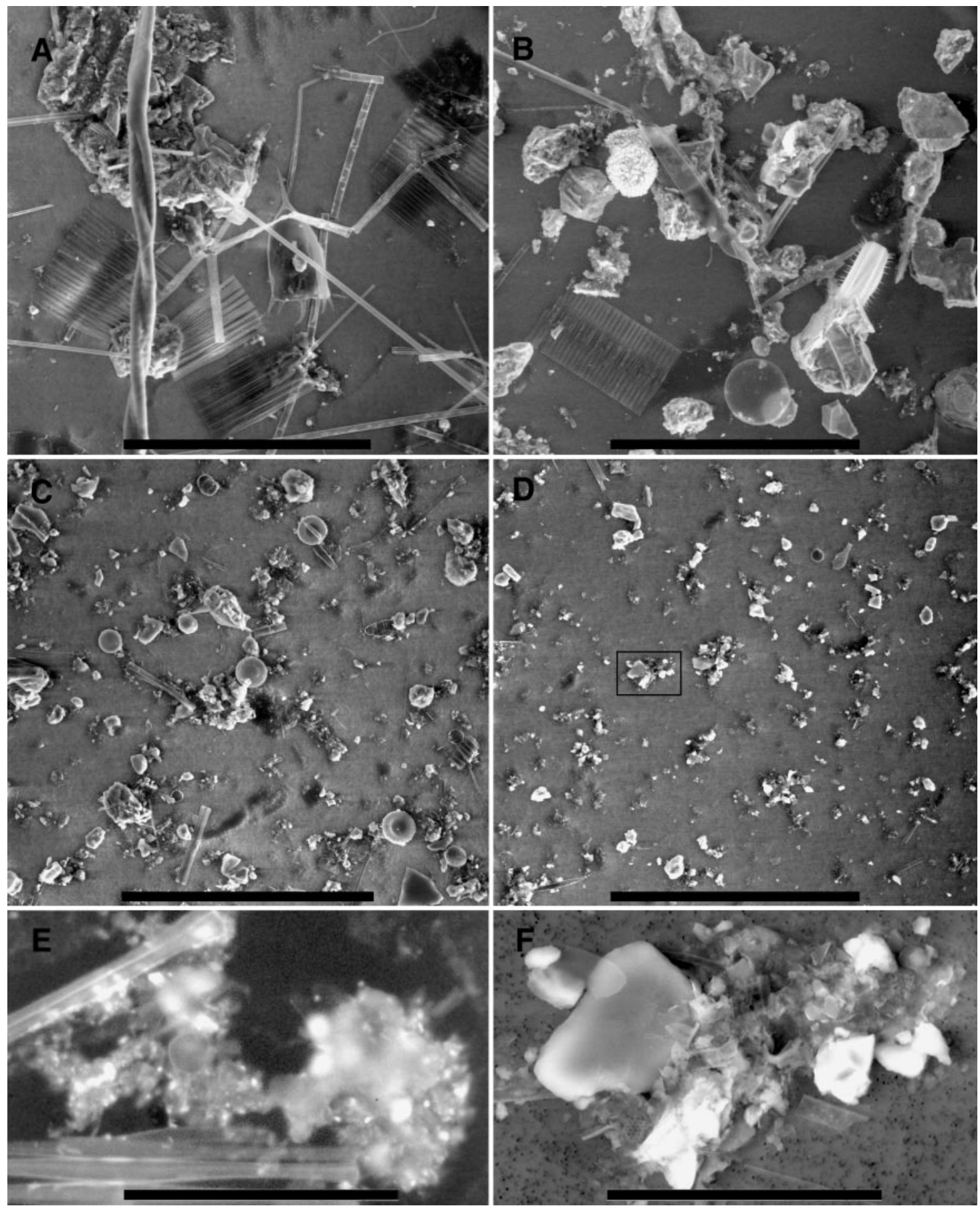

Fig. 7. Microscopic images of particles from the Columbia River estuary. Environmental scanning electron micrographs of size fractionated particles: (A) $>63 \mu \mathrm{m}$, (B) 20-63 $\mu \mathrm{m}$, (C) 10-20 $\mu \mathrm{m},(\mathrm{D})<10 \mu \mathrm{m}$, and (F) a close up of a particle from the $<10 \mu \mathrm{m}$ fraction. (E) DAPI stained particle viewed with fluorescence microscopy. Scale bars: (A-D) $200 \mu m_{i}$ (E) $50 \mu m_{\text {; }}(\mathrm{F}) 25 \mu \mathrm{m}$

gregation to occur during or after particles settle to the bed (Eisma \& Li 1993). The presence of such cycles in the Columbia River estuary would account for the high concentration of slow-settling bacterially-active particles found in Owen tube samples, because the samples were collected during the intermediate stages of ETM events after particles would have disaggregated.

Most of the bacterial activity was associated with faster settling particles in the other 3 ETM Owen tube samples. Macroaggregates exceeding $1 \mathrm{~mm}$ in diameter 
were often seen settling in Owen tube samples collected in some ETM and in images collected with an in situ video camera (data not shown). This shows that small, bacterially-active microaggregates combine to form larger, faster settling macroaggregates in the ETM, and that the degree of disaggregation can vary during any particular ETM event. Two samples (Fig. 3E,F) were collected during a neap tide when the extent of disaggregation in the ETM was probably diminished because of reduced water velocity and shear forces.

A large fraction of the suspended particulate material collected in Owen tube samples supported very little bacterial activity. Grain size analysis of particle settling fractions in the Columbia River estuary demonstrated that fast-settling particles were aggregates of smaller, slower settling particles (Reed \& Donovan 1994). So it is not clear why larger, faster settling aggregates are not always bacterially active. Faster settling particles probably host less bacterial activity $\mathrm{mg}^{-1} \mathrm{SPM}$, in part because they contain less organic matter (Table 3). It is also possible that faster settling particles are older aggregates that have been subjected to intense bacterial activity and no longer contain labile organic matter. Since less bacterially active aggregates settled more rapidly than active ones it is tempting to speculate that older aggregates are larger, denser, and more tightly bound than aggregates that support a rapidly growing bacterial community. This would also explain why they are not broken up early in the ETM cycle, and why they settle out of the water column rapidly after a resuspension event.

\section{Particle cycling in ETM}

It is not unusual to find that different particles cycle through estuaries in different ways. In the Jiaojiang River estuary in China, small clay-dominated 'dense' flocs were preferentially mixed up from the ETM and carried oceanward of the ETM where they either sank back to deeper water and were re-entrained in the ETM or were washed out of the estuary (Li et al. 1993). However, large silt-dominated 'loose' flocs, composed in part of dense flocs, were not lifted far off the bottom because they had faster settling velocities, or because they broke up in the stronger currents. In the Gironde estuary (France) large 'flocs' stayed in the ETM region by rapidly settling into deeper waters, while smaller flocs mixed into the upper layers of the water column and traveled far down-estuary before settling into deeper layers and being carried back up-estuary to the ETM (Gibbs et al. 1989).

In the Columbia River estuary, the appearance of high bacterial activity in the water column just before and just after peak water column turbidity during ETM events suggests that bacterially-active particles do not follow the same cycle as the majority of ETM particles. We have learned that bacterially-active particles are either slow-settling or are part of faster-settling, loosely-bound aggregates. Using this information we can construct a hypothetical model of how bacteriallyactive particles cycle in the ETM.

After a slack tide, most of the ETM material has settled to the bed or to a depth just above the bed. Sorting during the settling of these particles causes the slowersettling bacterially-active particles to be on the surface of the sediments, and the faster-settling particles to be deeper. As water velocity increases during a flood or ebb tide, the slowest settling particles are the first to be resuspended. This would account for the appearance of high bacterial activity in the water column early during an ETM resuspension event. Particles that are aggregated after settling to the bed undergo some disaggregation as they are lifted off the bed and mixed up into the water column, releasing bacterially-active particles into suspension. As water velocity increases and shear over the bed reaches a maximum, the bulk of the particles that constitute the ETM are resuspended and mixed up in the water column. Then, as water column velocity begins to slow, particles with the fastest settling velocity are the first to settle to the bed. Slow-settling bacterially-active particles remain in the water column until they settle to the bed either on their own or by forming loosely-bound macroaggregates.

This model has implications for the estuarine food web which, in the Columbia River estuary, is centered in the ETM. Detritivorous copepods, the most important metazoan grazers in the system, feed directly on ETM particles, and have been shown to directly consume particleattached bacteria (Simenstad et al. 1994b). The dominant copepod Eurytemora affinis migrates up and down in the water column with ETM particles in order to keep from being washed out of the estuary (Simenstad et al. 1994b, Morgan et al. 1997). Various points of evidence suggest that these copepods rise into the near-bed water column prior to the appearance of peak ETM turbidity (Simenstad \& Cordell unpubl.). As suspension feeders they may benefit from the sorting that occurs during resuspension events. They would encounter high concentrations of bacterially-active particles in the water column early during an ETM event when the particles are preferentially resuspended from the bed and again later when the particles stay in suspension longer than the less labile particles that make up the rest of the ETM.

\section{Conclusions}

Bacterially-active particles are concentrated in the ETM, but they do not cycle through the ETM in the 
same manner as most particles because they tend to be small, slow-settling particles that are easily disaggregated from large, rapidly-settling macroaggregates. The cycle followed by these particles places them in the water column longer than most ETM particles, making them more likely to be washed out of the estuary, but also making them more available to suspension-feeding detritivores. Formation of large, fast-settling macroaggregates in the later stages of flood and ebb tides and during slack tides is probably the mechanism by which bacterially-active particles are trapped in the ETM, and may be essential to maintaining the estuarine community of particle-attached bacteria.

Acknowledgements. This work was supported by National Science Foundation Land Margin Ecosystem Research Grant OCE-9412028. We thank Wendy Morrison and Denise J. Reed for assistance with the Quad Owen tube, Sheryl Bolton for assistance with sample collection and processing, Charles A. Simenstad for his work as chief scientist on the Columbia River ETM project, and the captain and crew of the RV 'Robert Gordon Sproul' for support in the field.

\section{LITERATURE CITED}

Chen S, Eisma D, Kalf J (1994) In situ distribution of suspended matter during the tidal cycle in the Elbe estuary. Neth J Sea Res 32(1):37-48

Crump BC, Baross JA (1996) Particle-attached bacteria and heterotrophic plankton in the Columbia River estuary. Mar Ecol Prog Ser 138:265-273

Crump BC, Simenstad CA, Baross JA (1998) Dominance of particle-attached bacteria in the Columbia River Estuary. Aquat Microb Ecol 14:7-18

Eisma D (1986) Flocculation and de-flocculation of suspended matter in estuaries. Neth J Sea Res 20:183-199

Eisma D, Li A (1993) Changes in suspended-matter floc size during the tidal cycle in the Dollard Estuary. Neth J Sea Res 31(2):107-117

Fuhrman J, Azam F (1982) Thymidine incorporation as a measure of heterotrophic bacterioplankton production in marine surface waters: evaluation and field results. Mar Biol 66:109

Gibbs RJ, Tshudy DM, Konwar L, Martin JM (1989) Coagulation and transport of sediments in the Gironde Estuary. Sedimentology 36:987-999

Goulder R (1977) Attached and free bacteria in an estuary with abundant suspended solids. J Appl Bacteriol 43:399-405

Heinle DR, Harris RP, Ustach JF, Flemer DA (1977) Detritus as food for estuarine copepods. Mar Biol 40:341-353

Editorial responsibility: Colin Levings (Contributing Editor), West Vancouver, British Columbia, Canada
Kranck K (1973) Flocculation of suspended sediment in the sea. Nature 246:348-350

Kranck K (1981) Particulate matter grain-size characteristics and flocculation in a partially mixed estuary. Sedimentology 28:107-114

Li Y, Wolanski E, Xie Q (1993) Coagulation and settling of suspended sediment in the Jiaojiang River estuary, China. J Coast Res 9(2):390-402

Milligan TG (1995) An examination of the settling behaviour of a flocculated suspension. Neth J Sea Res 33(2):163-171

Morgan CA, Cordell JR, Simenstad CA (1997) Sink or swim? Copepod population maintenance in the Columbia River estuarine turbidity maxima region. Mar Biol 129:309-317

Muschenheim DK, Kepkay PE, Kranck K (1989) Microbial growth in turbulent suspension and its relation to marine aggregate formation. Neth J Sea Res 23:283-292

Owen MW (1976) Determination of the settling velocities of cohesive muds. Report No. IT 161, Hydraul Res Stn, Wallingford, UK

Pejrup M (1988) Flocculated suspended sediment in a microtidal environment. Sediment Geol 57:249-256

Reed DJ, Donovan J (1994) The character and composition of the Columbia River estuarine turbidity maximum. In: Dyer $\mathrm{KR}$, Orth BJ (eds) Changes in fluxes in estuaries: implications from science to management. ECSA22/ERF symposium, Plymouth, September 1992. Olsen \& Olsen, Fredensborg, p 445-450

Sakamoto W (1972) Study on the process of river suspension from flocculation to accumulation in estuary. Bull Ocean Res Inst Univ Tokyo No 5

Schubel JR (1971) Tidal variation of the size distribution of suspended sediment at a station in the Chesapeake Bay turbidity maximum. Neth J Sea Res 5:252-266

Simenstad CA, Reed DJ, Jay DA, Baross JA, Prahl FG, Small LF (1994a) Land-margin ecosystem research in the Columbia River estuary: an interdisciplinary approach to investigating couplings between hydrological, geochemical and ecological processes within estuarine turbidity maxima. In: Dyer KR, Orth BJ (eds) Changes in fluxes in estuaries: implications from science to management. ECSA22/ERF symposium, Plymouth, September 1992. Olsen \& Olsen, Fredensborg, p 437-444

Simenstad CA, Morgan CA, Cordell JR, Baross JA (1994b) Flux, passive retention, and active residence of zooplankton in Columbia River estuarine turbidity maxima. In: Dyer KR, Orth BJ (eds) Changes in fluxes in estuaries: implications from science to management. ECSA22/ERF symposium, Plymouth, September 1992. Olsen \& Olsen, Fredensborg, p 473-484

Zimmermann H, Kausch H (1996) Microaggregates in the Elbe Estuary: structure and colonization during spring. Adv Limnol 48:85-92

Zweifel UL, Wikner J, Hagstrom A, Lundberg E, Norrman B (1995) Dynamics of dissolved carbon in a coastal ecosystem. Limnol Oceanogr 40:299-305

Submitted: July 2, 1999; Accepted: May 18, 2000

Proofs received from author(s): October 10, 2000 